\title{
Meeting The Needs \\ Of Rural Site-Bound Paraeducators
}

Mary Cathey White, (E-mail: CWhite@msubillings.edu), Montana State University George White, (E-mail: GWhite@msubillings.edu), Montana State University

Mary Susan E. Fishbaugh, (E-mail: MFishbaugh@msubillings.edu), Montana State University

\begin{abstract}
The Elementary and Secondary Education Act 2002-No Child Left Behind (NCLB) mandates that paraeducators who work with today's children and youth are highly qualified. Montana State University-Billings (MSU-Billings) has revised its Associate of Arts Program of Study in Education with the intention of supporting Montana and other rural states in complying with this mandate. In additioin to a two-year program of study at our main campus, the MSU-Billings College of Technology provides an exam for paraeducators with preparatory/remedial support modules.
\end{abstract}

\section{Introduction}

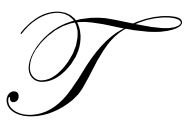

he 2002 revision and amendments of the Elementary and Secondary Education Act, commonly referred to as No Child Left Behind (NCLB) mandated that personnel working with children and youth in elementary and secondary schools be "highly qualified". In the case of paraeducators, those personnel who assist licensed teachers in delivering instruction, NCLB defines "highly qualified" as having two

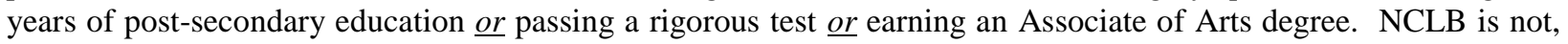
however, the only federal regulation that demands preparation for paras. Head Start regulations state that program staff should have an AA degree and that program directors earn a minimum of a bachelors degree. The Individuals with Disabilities Education Act (IDEA-97), that is in process for reauthorization, allows paras to assist with special education only if they have the skills and knowledge to meet the needs of the students being served. At the least, these three areas regulated by federal law-NCLB-Title 1, Head Start, and IDEA all require that paraeducators have knowledge of and ability to assist in the instruction of reading, writing, and mathematics.

Paras are essential in many classrooms (Goodnough, 2003; Likins \& Pickett, 2002). Teachers, trying to meet the needs of an increasingly diverse student population, rely on the extra help to address each student as an individual with unique learning strengths and weaknesses. While essential, paras are limited in the scope of responsibilities that they may shoulder and to a role of reinforcing what the teacher has introduced. Paras are continually under the direct supervision of a licensed professional; their role is not direct instruction of new material (French, 1999). Even if not introducing new material to be effective the para must be competent in the area that they are reinforcing/reviewing.

Even before federal legislation mandated highly qualified paraeducators, the National Resource Center for Paraprofessionals developed national standards for persons who serve in this role. Montana's Comprehensive System of Personnel Development Council (CSPD) has revised Paraeducator Academy Modules (Montana CSPD, 2004) based on these standards and developed at the University of Denver (French, 1999) for use in Montana. The CSPD Paraeducator Taskforce has offered the modules throughout the five regions of the state to better prepare paras. Even these pioneering efforts, however, do not go far enough to meet the letter or the spirit of current federal mandates. 


\section{Program Evolution}

MSU-Billings is unique in the Montana University System as the only public institution of higher education that offers both undergraduate and graduate degrees in special education. Montana requires that all future educators be licensed first in either regular elementary or secondary education. Special education is an added endorsement on that basic license and is a generalist endorsement. Montana graduates do not have the luxury of employment in settings devoted to educating specific types of disabilities. MSU-double majors are employed throughout the rural west, and in urban areas in the Midwest and on the west coast. In any setting, they may be serving students with a wide variety of needs. The uniqueness of our program and of the future employment responsibilities of our graduates has promoted our offering degrees in special education from Associate of Arts through Master of Science in Special Education and has made possible our current efforts to propose, develop, and implement a doctorate in the area.

Although there are two-year colleges in Montana, the Department of Special Education, Counseling, Reading, and Early Childhood at one time offered three AA degrees in areas of study unique to MSU-Billings-AA in Early Childhood Education, AA in Special Education, and AA in Rehabilitation Counseling. With reorganization of the institution and introduction of a new College of Allied Health Professions, the AA in Rehabilitation Counseling will no longer be offered by the College of Education. Recognizing the need for preparation to work in inclusive early childhood education settings, the AA in Early Childhood was combined with the AA in Special Education into an Associate of Arts in Inclusive Education. This programmatic mutation made evolution to the Associate of Arts Program of Study in Education a relatively easy transition for meeting the requirements of NCLB, Head Start, and IDEA.

\section{Program Content as Related to Standards}

The newly re-configured AA degree has two parts-General Education and Professional Education. General Education currently consists of 37 credits:

- Writing (6 credits)

- Oral Skills (3 cresits)

- Mathematics (3 credits)

- Natural Sciences (7 credits)

- Social Sciences (6 credits)

- History (3 credits)

- Cultural Diversity (3 credits)

- Fine Arts (3 credits)

- Integrated Humanities ( 3 credits)

NCLB requires that at a minimum paras be competent in reading, writing, and math. If they are working with students on content areas, they should also be competent in that area. The General Education package of our AA degree for paras is meant to address these requirements.

The Professional Education component of the AA degree focuses on the paraeducation role. Professional Education includes the following:

- Human Growth \& Development (3 credits)

- Introduction to Exceptional Learners (3 credits)

- Educational Technology Applications (2 credtis)

- Foundations of Reading (3 credits)

- Adult Child Interactions Skills (3 credits)

- Curriculum \& Adaptations (3 credits)

- Professional Roles and Expectations (3 credits)

- Internship \& Seminar (3 credits) 
NCLB primarily addresses reading ability/deficiency in learners. Therefore, we have resurrected RD 288 Foundations of Reading, a class that has not been offered for several years due to graduate credit limitations imposed by our state Board of Regents. This class is tailor-made for paras who need to understand the process of learning to read so that they can assist teachers in Title 1 reading programs. Head Start requires that service providers understand human development and can apply appropriate strategies for children who develop as expected and for those who vary from the norm. Human Growth and Development (EDF 225), Intro to Exceptional Learners (SPED 260), and Curriculum \& Adaptations (EC/SPED 283) meet this demand. IDEA requires that educatorswhether licensed or para - can use assistive technology with children and youth who need such supports. EDCI 210 Educational Technology Applications along with SPED 260 Introduction to Exceptional Learners address this content area. IDEA is particularly adamant with regard to the difference in roles between teacher and para; Professional Roles and Expectations (EC/SPED 289) dispels the myths and delineates appropriate responsibilities for these two very different roles. The internship and seminar provide a field experience with a supportive professional discussion for bridging the theory-to-practice gap.

This program meets the NRCP national standards for paras. There are six areas in these standards, each divided into knowledge and skills. Paras are expected eventually to reach Level III proficiency in all six areas both in knowledge and in skill. Standards areas with AA degree courses are outlined in Table 1.

Table 1: AA Program of Study in Education with National Paraeducator Standards

\begin{tabular}{|c|c|c|c|c|c|c|c|c|c|c|c|c|c|c|c|c|c|}
\hline 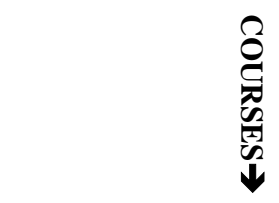 & : & 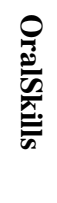 & $\stackrel{3}{\stackrel{3}{*}}$ & 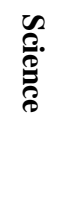 & 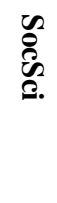 & 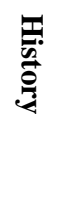 & 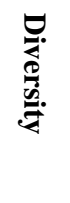 & $\frac{R}{5}$ & 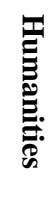 & $\begin{array}{l}\Omega \\
0 \\
0 \\
0 \\
0 \\
0\end{array}$ & 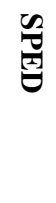 & 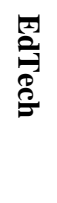 & $\begin{array}{l}\widetilde{\pi} \\
\text { हैं }\end{array}$ & 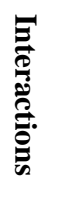 & 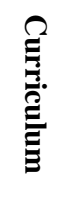 & $\frac{\overparen{Z}}{\bar{\theta}}$ & 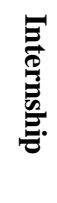 \\
\hline \multicolumn{18}{|l|}{ STANDARDS $\downarrow$} \\
\hline Team Member & & & & & & & & & & & $\mathbf{X}$ & & & $\mathbf{X}$ & & $\mathbf{X}$ & $\mathbf{X}$ \\
\hline LearnerCentered & & & & & & & $\mathbf{X}$ & & & & $\mathbf{X}$ & & & $\mathbf{X}$ & & $\mathbf{X}$ & $\mathbf{X}$ \\
\hline Planning & & & & $\mathbf{X}$ & $\mathbf{X}$ & $\mathbf{X}$ & & $\mathbf{X}$ & $\mathbf{X}$ & & & $\mathbf{X}$ & & & $\mathbf{X}$ & & $\mathbf{X}$ \\
\hline Asst w/ Children & $\mathbf{X}$ & $\mathbf{X}$ & $\mathbf{X}$ & & & & & & & $\mathbf{X}$ & & $\mathbf{X}$ & $\mathbf{X}$ & $\mathbf{X}$ & & $\mathbf{X}$ & $\mathbf{X}$ \\
\hline Asst w/Assessng & & & & & & & & & & & $\mathbf{X}$ & & & & & $\mathbf{X}$ & $\mathbf{X}$ \\
\hline Prof/EthConduct & & & & & & & & & & & $\mathbf{X}$ & & & & & $\mathbf{X}$ & $\mathbf{X}$ \\
\hline
\end{tabular}

\section{On-line Delivery}

Because Montana and other states in the area are predominantly rural, the AA degree is planned for on-line delivery. Western rural is very different from rural in other areas of the United States. With sparse populations and huge geographical areas, western rural means vast distances between population centers and schools that are not only rural but remote. Our distance course delivery, analogously to the degree itself, has evolved over time. As recently as 10 years ago, the instructor took a course to the location where there was demand, even demand of a few students. As Interactive Television (ITV) became available throughout a state, instructors could remain on campus but broadcast a course to several different locations at once and maintain same time (synchronous) life communication with the students. As computer technology has grown and become more accessible to more people, we have rapidly moved from an ITV to a computer platform for course delivery. On-line courses have several advantages over taking the course to the students and ITV. On-line delivery is less expensive, more reliable, and considerably more convenient for the student.

Currently, the Genreal Education courses are available on-line. Only part of the Professional Education courses have been developed and delivered through our on-line university capabilities. We plan to have the entire AA degree on a two-year distance delivery rotation within the next two academic years. The two-year rotation is similar to other degree programs and teacher preparation programs delivery through the College of Education. 


\section{Additional Opportunities}

There are paraeducators who have been working as teaching assistants for many years. Based on their years of experience and their age, many of these individuals do not perceive the expense of earning a two-year degree as enhancing their ability to do their job or economically cost-effective. For these individuals, the "rigorous test" proposed in NCLB may be the answer to keeping their present employment. The MSU-Billings College of Technology offers an exam for paras with modules for either preparation or remediation. The support modules assure that paras will have optimal opportunity for success with the exam.

An additional opportunity for experienced paras is portfolio development. The Montana Center on Disabilities, a service arm of the College of Education in cooperation with the CSPD Paraeducator Taskforce is developing a portfolio framework through which paras can demonstrate the expertise necessary for fulfilling their instructional responsibilities.

MSU-Billings has as its motto "Access and Excellence". In terms of preparing highly qualified paraeducators, we are living true to our motto. We have developed a program of study based upon legal requirements and national standards. This program will be available on-line for place-bound paras. And if a degree is out-of-the-question, we have a rigorous test with support modules available and a portfolio process being developed for demonstrating proficiency.

\section{References}

1. Council for Exceptional Children. (1997). Working with paraeducators. CEC Today, 4(3), 1, 5.

2. French, N. (1999). Paraeducator supervision academy. Denver CO: University of Colorado at Denver: Center for Collaborative Educational Leadership.

3. French, N. (1999). Supervising paraeducators - What every teacher should know. CEC Today (September).

4. Goodnough, A. (2003). Views differ about aides in classrooms. New York Times. www.nytimes.com/ 2003/05/19/nyregion/19AIDE.html?th.

5. Head Start. United State Department of Health and Human Services: Administration for Children and Families. www.acf.hhs.gov.

6. Individuals with Disabilities Education Act. Council for Exceptional Children. www.cec.sped.org.

7. Individuals with Disabilities Education Act. National Association of State Directors of Special Education. www.nasdse.org.

8. Likins, M. \& Pickett, A.L. (2002). Paraeducators: Completing the team. Billings MT: Montana Summer Institute, June 10-11.

9. Montana Comprehensive System of Personnel Development. (2004). Paraeducator academy modules. Helena MT: Montana Office of Public Instruction. CSPD Council. Paraeducator Taskforce.

10. National Resource Center for Paraprofessionals. www.nrcpara.org.

11. No Child Left Behind. United State Department of Education. www.ed.gov.

12. Pickett, A.L. (1999). Strengthening and supporting teacher/provider-paraeducator teams: Guidelines for paraeducator roles, supervision, and preparation. New York: City University of New York: National Resource Center for Paraprofessionals in Education and Related Services. Center of Advanced Study in Education. Graduate Center.

13. Pickett, A.L. (2000). The trained paraprofessional: It's not just a job, it's a requirement. The Special Educator, 15(12), 1, 6-7.

14. U.S. Dept of Education: Office of Special Education Programs. (2003). Paraeducators. Research Connections in Special Education (12) (Spring). 